\title{
The Connotations and Integration Development of the Red Culture
}

\author{
Jianping Liu $^{1, a}$ \\ ${ }^{1}$ Sichuan Agricultural University, Ya'an, Sichuan, China, 625014 \\ aemail,
}

Keywords: Red Culture, Integration Development, National Culture, Red Tourism

\begin{abstract}
Chinese red culture originated in the May Fourth Movement to Marxism-Leninism as the ideological and theoretical basis, the CPC led the Chinese people's anti-imperialist proletarian seal feudal political culture. Meanwhile, with the development of the times, the connotation of red culture changes with the times, with different content at different stages of the Chinese revolution, reform and construction. In the development and utilization of the red cultural resources in the process, we found that relying solely on its own red and cultural resources as well as the way is still some limitations, therefore, take the "red culture + " fusion development, the development of breakthrough red culture.
\end{abstract}

\section{Introduction}

Chinese periodical database from the information point of view, on the red and cultural issues related to research from 2003, in which the concept of "red culture" began to appear from 2004, before the reference is "red cultural resources." Since 2004, the red circle on the culture a lot of research, although so far not given "Red Culture" a complete definition academically, but scholars generally believe that "red culture" is the Chinese Communist Party led the Chinese people in the long term revolution and construction practice of accumulation, creation, integration of a particular type of culture formed up.

Under the Chinese context, more often red culture belongs to the category of political concepts. In the "Ci Hai", the red are the following explanation: communism, the Communist Party of China and the related revolutionary "left" politics and so on. Red Chinese culture originated in the May Fourth Movement to Marxism-Leninism as the ideological and theoretical basis, the CPC led the Chinese people's anti-imperialist proletarian seal feudal political culture. Meanwhile, with the development of the times, the connotation of red culture changes with the times, with different content at different stages of the Chinese revolution, reform and construction. But in view of its manifestations, regardless of what stage, it is constituted by the two levels of substance culture and spiritual culture.

\section{The Connotation of Red Cultural}

The Content of Red Culture. The main content of the red culture before New China was founded. From the New Culture Movement to the period before the founding of New China, mainly in the red culture "revolutionary" content-based culture, "national, scientific and popular culture of New Democracy" is the main form of red culture at this stage.

New Culture Movement and the party's founding period, infancy is red Chinese culture, when the Marxist-Leninist ideology that is just introduced into China, to accept this new ideas who are mainly very small part of the advanced intellectual and cultural acceptance surface and the radiation surface is extremely limited, red culture as a form of existence of elite culture. The main content of the early red culture, it is embodied in advanced intellectuals Marxism recognition and dissemination, and Marxism as observing, thinking, way to solve the problem of China to establish its belief in Marxism and communism ideology.

After the May Fourth Movement, the red cultural elite culture to regional cultural change, the revolutionary spirit of self-reliance, hard work is the main content of this period the red culture. After the May Fourth Movement, the Marxist ideology to be more widely spread, with the 
establishment of the Chinese Communist Party and the labor movement in the country set off a climax, the red cultural connotation of the revolutionary spirit awakened countless people. Red culture has gone through three regional Soviet Red Culture, Japanese Base and Liberated culture red culture cultural stage, it is integrated into a firm spirit of patriotism, and the continuation of traditional rural culture and heritage of the feelings of patriotism, whose main task is play cultural enlightenment, political and propaganda war mobilization purposes.

Red culture before the founding of New China, the Chinese Communists is Marxism-Leninism, Mao Zedong Thought under the guidance of the collective wisdom and hard crystallization of Marxism in China during the first a form of culture, it belongs to a proletarian culture part is national, scientific, cultural, core mass revolutionary culture, red culture of this period is the main form of red circles alleged culture.

The main contents of red culture after the founding of New China. After the founding of New China, scholars generally red culture will evolve into two periods before the reform and opening up and reform and opening up.

Prior to the founding of New China's reform and opening, red culture by the regional culture to the mainstream culture process of rising, the Communist Party of China led the Chinese people in the new democratic revolution on the basis, in Marxism-Leninism, Mao Zedong thought, and the socialist revolution historical period of socialist construction. Red culture of this period inherited the cultural connotation of the founding of the red before, but also has the unique characteristics of the times. After the founding of the red cultural patriotism, collectivism, socialism connotation motivate people, adhere to the spirit of the revolution, it is a symbol of a generation of spiritual beliefs.

After the reform and opening up, red culture gradually be integrated into the socialist core value system, and resources in the form of red manifested. Red resources namely CPC led the Chinese people of all ethnic groups formed in the revolutionary struggle and construction practice in the great support. Through the development of cultural industries red, red tourism, red resources to explore ways to dig deep red resources, a greater level of development and utilization of resources is red theory and social practice topic of common concern.

Overall, on a narrow, red culture is the Chinese Communist Party led the Chinese people work hard, Xinmin revolution in the process of evolving new democratic culture is the main core. Broadly, red culture from the beginning of the New Culture Movement until now, it continues to advance with the times, rising from the elite culture of regional culture, to the mainstream culture, socialist culture with Chinese characteristics is a red inheritance cultural content, its meaning of hard work, and dedication of the spirit of the revolution belongs to the category of red culture.

The Manifestations of Red Culture. According red culture presented in the form of a red circle will be divided into physical form and spiritual cultural forms. Physical form refers to the external manifestation of the red culture, red culture content presentation carrier.

We see red cultural resources, mainly relics, buildings and facilities, cultural activities in three categories. Revolutionary relics such as meeting sites, House leaders, and other battlefield memorial, Luding County, Ganzi Prefecture in Sichuan Luding Bridge, Moxi town meeting site, the Autumn Harvest Uprising in Hunan rendezvous site in this category. Building and facilities such as Revolutionary Memorial Hall, martyrs cemetery, memorial and other leaders, Zhu De and the 5th Living Buddha Geda Memorial, Guang'an Deng Xiaoping's Former Residence and Memorial belong to this category. Human activity is the performance of principal content revolution, revolutionary spirit, revolutionary process of cultural works such as novels, articles, songs, and other publications.

Form refers to the inner spiritual manifestations red culture and red culture is the main content, including ideals, beliefs and ideology. Spiritual form red culture in different historical periods have different content, before the founding of New China, its core content is the cultural revolution, the Chinese Communist Party in Marxism-Leninism, Mao Zedong Thought under the guidance of the collective wisdom and hard crystallization of Marx Marxism in China during the first cultural patterns. After the founding of new China, red culture inherited revolutionary spirit, hard work and 
other core content, and integration with the socialist core value system, it has become a symbol of the spirit. After years of fiery red culture trained, with broad popular support and recognition of the value, which is the most important carrier of the Communist Party of China Political Identity continuation and expansion.

\section{The Fusion Development of Red Cultural}

Nationwide, the development and utilization of the red cultural resources has made a major breakthrough whether in reality or in theory community. But there are still many problems, such as insufficient integration of resources, product features, etc. is not clear, therefore, strengthen the development of cultural integration in red, take the "red culture + " on the road, to facilitate the full integration of resources, develop more reasonable red cultural products . For now, the integration path red culture are mainly domestic development of regional integration, multi-cultural development, tourism industry and the development of three red cultural integration.

Regional Integration Development. Long March route is realistic basis to build regional integration development mechanism. Regional integration development is conducive to more remote location of the regional development red cultural resources. For example, Ganzi Tibetan Autonomous Prefecture, Sichuan Province Red Army activities focused on Liangshan, Ya'an, Garze and Aba and other places, leaving a lot of valuable red cultural resources. Ganzi, Sichuan is located in the west, due to the geographical environment is relatively harsh and inaccessible, has seriously affected the development and utilization of Ganzi red cultural resources. Ganzi to break the geographical restrictions, must effectively integrate cultural resources red Ganzi and the surrounding area, take the red and cultural resources of regional integration model, to create brand-name red area in western Sichuan.

Red and cultural resources within the same region tend to have a strong correlation, with reasonable and necessary resource integration. To build a regional integration mechanism should be implemented four-step strategy: First, under the government-led, official and non-governmental exchanges to strengthen inter-regional, regional cooperation to build a platform. On the one hand, through official exchanges between local governments, break the regional barriers and achieve mutual sharing of information is conducive to the effective integration of the red cultural resources. The exchange of non-governmental organizations on the other hand enterprises, universities, etc., will help strengthen the red cultural resources for research and innovation, at the same time, more conducive to the realization of complementary advantages between regions. The second is in the red area inventory cultural resources, rational planning of resource integration path. In order to integrate the region red resources, the need multi-collection force governments, research institutions, and other people, to find out the status of conservation and development in the region red cultural resources, to find a breakthrough in the integration. For example Ganzi and Liangshan, Ya'an three respective advantages, such as unique Ganzi and Liangshan geographical environment, rich natural resources and human resources. Ya'an is the gateway to western Sichuan, Chengdu close distance, regional location, and 211 national colleges and universities located in Ya'an City, Sichuan Agricultural University, its strong scientific research strength to be able to integrate the three resource tremendous boost. Fourth, the integration of the region in red, eco-tourism resources, set inter-regional experiential tours. In recent years, the prevalence of the country riding, hiking, "sports and leisure" has become a new fashion moment.

The Development of Multi-Cultural Integration. Produce cultural content so far from the red, nearly a hundred years of history, it is the formation of multiple integrated development model with Chinese traditional culture, national culture, campus culture, network culture. Among them, the integration of culture and the minority culture of the red, red is an effective way to play a cultural complex of political and economic value.

Firm ideals and beliefs contained in red culture, daring spirit of the new road, relying on the masses and work style are thought strengthening party building, an important part of maintaining the advanced nature of the Communist Party. Red advanced cultural connotation of the spirit of the same strain and the Party's advanced nature, it is the Chinese Communist Party's magic. For 
example, Ganzi Prefecture in Sichuan, Ganzi on existing cultural resources red, the red cultural resources existing form and content of both showed significant Tibetan characteristics. Zhu De as commander in chief and the 5th Living Buddha Geda Memorial precisely established to commemorate the victory of the Red Army and the Living Buddha Geda V recall merit. Red and cultural resources of Ganzi Tibetan architectural blend of architectural styles, including the Red fly won the Luding Bridge Memorial is a typical example of an integrated Chuanximinju, Tibetan architecture, ancient Ming and Qing buildings. "A distinctive, good spiritual connotation of regional culture in the region can make external establish a good, deep image of the region, which for the region to attract foreign investment and talent to strengthen economic exchanges and cooperation with the outside of great benefit. "in order to better develop and make good use of Ganzi red and cultural resources, and tap its economic value, by the State Council poverty Alleviation Office, Sichuan Provincial Government and the China Export-Import Bank jointly launched the" red Army to protect the site and Promotion of tourism development in Ganzi project " officially launched in 2011, the Red Army memorial in Ganzi Xiangcheng is one of the first projects in the works.

The Integration Development of Tourism Industry and Red Cultural. Domestic as Jiangxi, Hunan, Guizhou, Sichuan, Chongqing, Shaanxi, Shandong and other places are seeking to develop tourism, and the red tourism products with special characteristics, but the red and green tourism as compared to the heat of eco-tourism, there is a gap. For this reason, many domestic by relying on its existing green tourism infrastructure, "green" with "red", red to green tourism resource injection culture, formation of the red tourism and green tourism complementary pattern.

Eco-tourism resources in most areas and red cultural resources have great relevance. For example, Ganzi Tibetan Autonomous Prefecture, its geographical location, the Red Army within the scope of activities are concentrated in the Ganzi today well-known eco-tourism attractions, or around, such as the Marco Polo Bridge, Moxi Catholic Church (Moxi meeting site) and Garze with famous attractions in Ganzi Hailuogou Luding County. Similarly, the famous tourist attractions in Ganzi Daocheng Aden because of its unique geographical environment and natural climate visitors, but few people know Daocheng Aden is also a gathering place for the red of Culture. May 1936, Red Army Sixth Corps enter Daocheng, Daocheng County Township in and near the town of Kim tie Okimura stayed for nearly 10 days, by the Daocheng County Daocheng County is planning to near Township and red tie Okimura tourism line, they are practical action to verify the feasibility of the red and green tourism and cultural combination.

"Red" and "green" development ideas of combining the old revolutionary base in the domestic part to successful verification, and has accumulated rich experience. In Guizhou, Guizhou Xishui through the "red with green, red and promote green, red and green dance" of Culture Tourism, broadening the local tourism development ideas, attracted a large number of foreign tourists, it has formed a habit County water brand characteristics, in order to focus on contiguous poor areas of Guizhou Province poverty Alleviation made a useful exploration.

Red is the Chinese Communist Party culture, and advanced elements of the masses in revolutionary practice together to create a highly advanced culture system with Chinese characteristics and it is a new economic growth point, but also to maintain social stability and spiritual support. Exploitation red cultural resources should adhere to scientific development, the path of sustainable development, in order to avoid the purely economic interests while ignoring the red culture inherent cultural values and educational function, the only way to better carry forward the tradition and spirit of the red cultural, rising red the social value of culture.

\section{Acknowledgements}

Fund Project: Sichuan Old Revolutionary Areas Development Research Center Project (SLQ2014C-13)

\section{References}

[1] Red Army in Sichuan. Sichuan Provincial Academy of Social Sciences Publishing House, 1986 
[2] Bao Yongxin, Wang Yunhui, Wang Qunyong. Yan'an University, Vol. 2 (1989) No 27, p.74-76

[3] Zhong Xiuli, Jing Jianfen, Hou XuSiem. Ruling Culture, Vol. 11 (2007) No 19, p.144-145

[4] Guan Shiting. Cultural Construction, Vol. 13 (2012) No 27, p.21-23

[5] Wei Yan, Sun Jing. Shandong Youth Political College, Vol.29 (2013) No 1, p.57-60

[6] Xu Xuechu. Southwest University for Nationalities, Vol.10 (2006) No 27, p. 81-85

[7] Zhang Youheng, Jing Jianfen. Tianfu New Theory, Vol. 5 (2007) No 19, p.144-145

[8] Hu Song. Gannan Normal University, Vol. 5 (2009) No 27, p.21-23

[9] Wei Benquan, Sun Jing. Shandong Youth Political College, Vol.29 (2013) No 1, p.57-60

[10] Liu Kun. People's Forum, Vol. 2 (2012) No 27, p.52-54

刘建平,四川省雅安市雨城区四川农业大学新校区 20 栋,邮编:625014.

电话:18783500191 